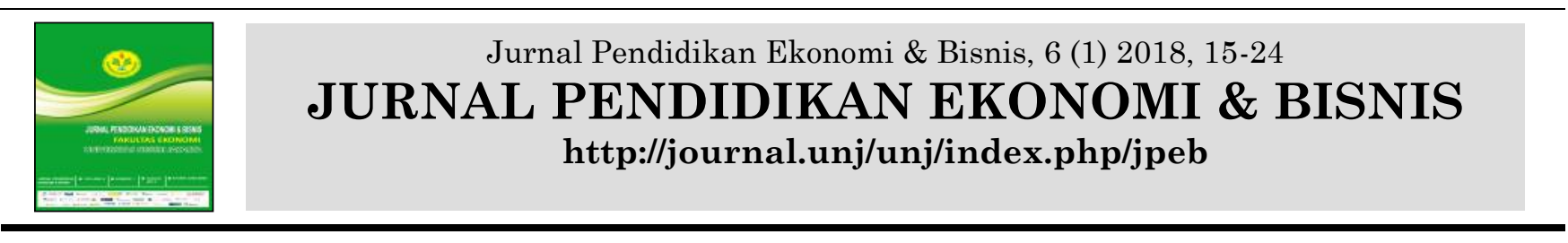

\title{
Model Pembelajaran Syariah di Jurusan Akuntansi
}

\author{
Krisno Septyan ${ }^{1}$, Wisnu Julianto ${ }^{2}$ * \\ ${ }^{1}$ Fakultas Ekonomi dan Bisnis, UPN Veteran Jakarta, Indonesia \\ 2 Fakultas Ekonomi dan Bisnis, UPN Veteran Jakarta, Indonesia
}

\section{Article Info}

Article history:

Received: 17 January 2018;

Accepted: 1 February 2018;

Published: 1 March 2018.

Keywords:

Fiqih muamalah; Islamic accounting; Teaching

\begin{abstract}
This research is aim to propose practically in Islamic accounting teaching to input fiqih muamalah and accountig are balanced. This research method is used critical Islamic accounting teaching based on prime of law source of Islam. This research shows that students and graduates have risks if department of accounting has no teach fiqih muamalah and department of accounting will be achieved learning outcome for students and graduates if fiqih muamalah became part of teaching in Islamic accounting. We offer several ways to apply fiqih muamalah be a part in Islamic accounting teaching are (1) fiqih and accounting should be balance, (2) make two course accounting teaching like as intermediate accounting (Islamic accounting part 1 and part 2), (3) removing similliar discussion in Islamic accounting with financial accounting and (4) lecture make a literature about fiqih muamalah for student to independently studying.
\end{abstract}

\begin{abstract}
Abstrak
Penelitian ini bertujuan menawarkan secara praktik pengajaran akuntansi syariah untuk memasukan fiqih muamalah dan akuntansi secara seimbang. Metode penelitian ini menggunakan paradigma kritis untuk mengkritisi pembelajaran akuntasi syariah berdasarkan sumber hukum Islam. Penelitian ini menunjukan bahwa mahasiswa dan lulusan memiliki risiko jika Juruan Akuntansi tidak mengajarkan fiqih muamalah, serta capaian pembelajaran jika fiqih muamalah dimasukan sebagai bagian pembelajaran akuntansi syariah. Peneliti menawarkan beberapa metode untuk menerapkan fiqih muamalah tersebut yaitu: (1) fiqih dan akuntansi diterapkan secara seimbang; (2) membuat dua mata kuliah seperti akutansi intermediate 1 dan 2, begitu juga dengan akuntansi syariah 1 dan 2; (3) menghapus bahasan sama yang terdapat dalam mata kuliah akuntansi syariah dengan akuntansi keuangan, dan (4) dosen membuat literatur mengenai fiqih mumalah bagi mahasiswa untuk dipelajari secara mandiri
\end{abstract}

How to Cite:

Septyan, K.,\& Julianto, W. (2018). Model Pembelajaran Syariah di Jurusan Akuntansi. Jurnal Pendidikan Ekonomi \& Bisnis, 6 (1) 2018, 15-24.
* Corresponding Author. kris.tyan26@gmail.com (Krisno Septyan) antoacid@gmail.com (Wisnu Julianto) 


\section{PENDAHULUAN}

Berkembangnya entitas syariah di berbagai dunia, ternyata juga diikuti dengan regulasi terkait. Tujuannya tidak lain untuk memfasilitasi operasional bisnis formal syariah tersebut. Berkaitan dengan hal tersebut, dunia pendidikan juga mulai mengimbangi agar lulusan dapat menjadi tenaga yang handal dan dapat bersaing saat memasuki dunia bisnis, khususnya entitas syariah yang sedang berkembang.

Sayangnya, lulusan-lulusan perguruan tinggi bidang akuntansi banyak mengakomodasi kepentingan pasar modal, serta hanya tunduk dan patuh pada kepetingan stockholder. Tidak hanya pendidikan formal, tapi juga pendidikan non formal di arahkan pada kebutuhan perusahaan sehingga terfokus pada bidang-bidang teknis. Temuan Clayton (2012), dan Mulawarman (2008) sampai pada kesimpulan bahwa fresh graduated's dianggap tidak memiliki alat yang memadai dalam membantu perusahaan menyelesaikan masalah-masalah efisiensi, transparansi, professional, kecepatan adaptasi, kemampuan gagasan, serta penyajian laporan keuangan.

Dalam akuntansi syariah, teori yang paling tepat adalah syariah entreprise theory. Teori ini merefleksikan hubungan yang harmonis dan peduli terhadap semua stakeholder. Bahkan, dalam perusahaan pun dikenal stakeholder tertinggi yaitu Tuhan. Berdasarkan teori tersebut akuntansi dilihat sebagai paradigma spiritualis, di mana kesadaran akan dikembalikan pada keberadaan Tuhan sebagai tempat bergantung. Menurut Triyuwono (2013), teori tersebut lebih lengkap karena mencakup aspek sosial dan pertanggungjawaban. Agar entreprise theory menjadi syariah, lanjut Triyuwono, maka Tuhan di masukkan sebagai stakeholder tertinggi.

Adapun syariah dimaknai sebagai aturan. Jika yang dimaksud adalah aturan Islam, maka syariah akan merujuk pada sumber aturan (hukum) yaitu al Quran dan hadits. Dengan demikian dapat disimpulkan bahwa entitas syariah adalah entitas yang beroperasi atas dasar Alquran dan hadits. Dapat dicontohkan seperti bank syariah adalah bank yang bergerak atas dasar Alquran dan Hadits di mana bank syariah tidak men- jalankan transaksi-transaksi riba karena dalam QS 2: 275 terdapat pelarangan riba. Sehingga bank syariah mencari alternatif lain, yaitu seperti menggunakan akad jual beli, bagi hasil, sewa dan sebagainya. Ada juga bank yang tidak menggunakan nama syariah, tetap menggunakan sistem bagi hasil dan tidak menggunakan bunga, lalu apakah bank ini juga akan dinamakan syariah jika bank tersebut tidak merujuk pada Alquran dan Hadits? Jawabannya tentu tidak.

Jika ditarik kembali pada mata kuliah yang memiliki ciri kesyariahan dipertanyakan kembali apakah dasar pengadaan mata kuliah tersebut atas dasar Al Qur'an dan hadits, maka mata kuliah tersebut akan mencapai pada makna syariah itu sendiri dan akan mengembalikan kesadaran kepada Tuhan. Sehingga metode pengajaran menjadi pengajaran berbasis ketauhidan dan dakwah. Hal ini dapat menjadi pengamalan pengajar yang sangat berharga karena sesuai beberapa sumber hukum Islam

Mulawarman (2006) menjelaskan bahwa sistem pendidikan saat ini telah lepas dari realitas masyarakat Indonesia disebabkan sistem dan konsep pendidikan akuntansi di Indonesia di adopsi dari luar negeri. Yang belum tentu keadaan negara lain cocok diterapkan di Indonesia. Sebagai bukti bahwa peraturan-peraturan akuntansi di setiap negara bisa berbeda dan dibuat sesuai iklim ekonomi negara tersebut.

Seperti contoh Akuntansi Amerika Serikat telah menjadi sumber utama Indonesia. Mulawarman (2008) menggali lebih dalam bahwa konsep pendidikan akuntansi di Amerika Serikat merupakan hasil evolusi sistem pengembangan pendidikan yang terangkum dalam American Accounting Association's Bedford Committee Report, perspective on Education dari Kantor akuntan public yang saat itu the Big 8 dimotori oleh Arthur Andersen. Padahal, ditutupnya kantor tersebut menunjukan konsep pembelajaran akuntansi yang gagal, karena masih berfokus pada kepentingan pasar modal dan stockholder.

Dari berbagai macam mata kuliah yang ditawarkan dalam proses pembelajaran akuntansi, terdapat mata kuliah menarik 
yang meleburkan dinding sekulerisme yaitu akuntansi syariah. Berbeda dengan akuntansi yang sudah dibahas sebelumnya bahwa belum tentu setiap negara memiliki iklim yang sama, menariknya akuntansi syariah dapat diterapkan di berbagai negara, di mana standar akuntansi syariah banyak diadopsi dari negara timur tengah yaitu Bahrain dalam standar yang dibentuk oleh Accounting and Auditing Organization for Islamic Financial Institution (AAOIFI). Hal ini menjadikan hikmah bahwa sumber hukum Islam dapat diterapkan diseluruh negara.

Mengingat beragamnya standar akuntansi, berbagai macam yang dilakukan dunia pendidikan yang tidak berbasis syariah pun mulai memunculkan program studi syariah, mata kuliah syariah, dan lainnya terkait dengan syariah. Hal tersebut dikarenakan kebutuhan pasar serta kredibilitas dunia pendidikan dalam memfasilitasi pasar tenaga kerja nantinya. Seperti contoh, pada program studi akuntansi yang umum (bukan program studi akuntansi syariah) telah membuka bahkan menjadikan akuntansi syariah sebagai mata kuliah wajib.

Namun apakah nama syariah benarbenar menjiwai makna syariah itu sendiri atau hanya sekedar memenuhi kebutuhan pasar. Menurut Triyuwono (2012) akuntansi syariah merupakan mata kuliah yang meleburkan dinding sekulerisme dan mengembalikan kesadaran kepada Tuhan. Berdasarkan pendapat Triyuwono tersebut mestinya mata kuliah akuntansi syariah menghasilkan etika pada lulusannya, agar memliki sikap tanggung jawab serta merefleksikan bahwa manusia sebagai bagian yang dipantau oleh Tuhan sebagai stakeholder tertinggi.

Kajian terkait pentingnya akuntansi syariah dilakukan oleh Gaffikin (1997); Triyuwono dan As'udi (2001:27). Penelitian ini memang membahas pentingnya pengajaran syariah, tetapi tidak spesifik di perguruan tinggi. Selanjutnya Penelitian Meier Kamat (2010), lebih spesifik pada kecurangan etika akibat gagalnya pengajaran syariah dalam berbagai mata kuliah. Jika kajian-kajian sebelumnya tidak menawarkan model pembelajaran yang tepat, maka penelitian ini berusaha mengisi celah-celah yang belum dibahas oleh peneliti sebelumnya, terutama terkait keseimbangan bahasan syariah dalam mata kuliah akuntansi.

Penelitian ini menjadi penting mengingat temuan Meier, Kamath, \& he (2010), menyebutkan banyak kasus kecurangan di lapangan akibat tidak seimbangnua bahasan syariah dalam pengajaran akuntansi. Apalagi, selama ini kritikan terus tertuju pada universitas-universitas untuk menentukan bagaimana program akuntansi menyiapkan lulusan yang siap untuk mencegah dan mendeteksi kecurangan dimasa mendatang. Sehingga studi-studi ini masih menunjuk bagaimana melakukan pencegahan penggelapan dan sejenisnya yaitu dengan cara adanya pembelajaran audit forensic, jauh dari itu semua, yang harus dikoreksi adalah bagaimana lulusan akuntansi dapat bertanggung jawab terutama pada dirinya sendiri yaitu pada sistem perkuliahan di perguruan tinggi atau kampus.

Hal tersebut didukung dengan dugaan peneliti bahwa mengapa yang menjadi sampel adalah perguruan tinggi? Peneliti juga menggunakan obesrvasi dalam menguatkan dugaan, yaitu pada ranah Sekolah Menengah Kejuruan (SMK) dengan cara memberikan seminar sebagai guru tamu. Peneliti memberikan materi fiqih muamalah dan akuntansi syariah dengan peserta dari dua jurusan yaitu jurusan akuntansi dan jurusan perbankan syariah. Hasilnya, adalah siswa SMK masih peduli terhadap nilai syariah dengan melihat banyaknya pertanyaan yang diajukan terutama menyangkut transaksi syariah dalam kehidupan sehari-hari dibanding bidang akuntansi.

Berdasarkan uraian di atas, maka seberapa besar pemahaman mahasiswa khususnya yang beragama muslim dalam mempraktekan memilih transaksi-transaksi yang halal dan meninggalkan transaksi non halal. Hal ini tentunya dikaitkan dengan seberapa besar komposisi fiqih muamalah dalam mata kuliah akuntansi syariah. Jika akuntansi 
syariah berfokus pada penyajian, pencatatan, penjurnalan dan sebagainya terkait dengan angka-angka, maka akuntansi syariah tidak memliki nilai yang berbeda dengan akuntansi biasa.

Lebih dari itu, lulusan tidak akan peduli apakah proses penghasilan nantinya bersumber dengan yang tidak bertentangan syariahkah atau tidak. Padahal Rasulullah SAW bersabda: "akan datang suatu masa, orang-orang tidak peduli dari mana harta dihasilkannya, apakah dari jalan yang halal atau dari jalan yang haram” (HR. Bukhari)

\section{METODE}

Penelitian ini menggunakan metode penelitain kualitatif dengan pendekatan etnografi di mana peneliti sebagai partispan yaitu pengajar subjek. Peneliti menekankan beberapa pertentangan jiwa antara idealisme dunia pendidikan yang menggabungkan spiritualisme dengan realitas yang terjadi di lapangan yang membuat dampak negatif serta memurnikan filosofi dasar akuntnsi syariah dengan paradigma kritis yang memungkinkan menuju pada paradigma spiritualis di mana tujuan akhirnya adalah mengembalikan kesadaran kepada Tuhan (Triyuwono, 2013).

Hasil analisis tersebut berdasarkan sumber hukum utama Islam yang menjadi acuan tertinggi, kemudian didukung penelitian terdahulu dan hasil observasi. Peneliti melakukan dugaan terlebih dahulu dengan menghitung persentase bahasan fiqih muamalah dengan bahasan akuntansi pada akuntansi syariah pada Silabus beberapa perguruan tinggi yang bisa diakses dan diunduh secara umum melalui internet. Pada beberapa perguruan tinggi di Indonesia hasil di atas diperoleh jumlah bahasan menunjukkan bahwa rata-rata pengajaran akuntansi syariah pada jurusan akutansi umum memiliki komposisi bahasan akuntansi (jurnal hingga pelaporan keuangan) lebih banyak dibandingkan fiqih muamalah, yaitu $62 \%$ komposisi akuntansi dan 38\% komposisi keIslaman (fiqih muamalah dan hal lain terkait syariah Islam).

Peneliti tidak mengambil sampel pada jurusan atau perguruan tinggi berbasis syari- ah karena pada jurusan basis syariah biasanya sudah memiliki mata kuliah pra akuntansi syariah seperti fiqih muamalah, ushul fiqih dan sebagainya terkait dengan kesyariahan sehingga metode dakwah pada mata kuliah akuntansi syariah di jurusan yang berbau syariah tidak lagi masuk menjadi sampel penelitian ini dalam melakukan dugaan awal.

Walaupun pada jurusan akuntansi umum memiliki mata kuliah pendidikan agama Islam, mata kuliah tersebut lebih banyak berfokus pada aqidah, fiqih ibadah, dan akhlak, sedangkan teknis (yang berkaitan dengan ekonomi atau fiqih muamalah) menunjukan presentasi yang sedikit pada mata kuliah Agama Islam. Sehingga data empiris yang diperoleh memperkuat fiqih muamalah penting diterapkan dan besaran bahasannya menjadi pertimbangan dalam mata kuliah akuntansi syariah di jurusan akuntansi umum.

Adapun observasi yang dilakukan adalah dengan melakukan wawancara pada perguruan tinggi yaitu Universitas Indonesia (dosen), Kalbis Institute, UPN Veteran Jakarta dan Universitas Trisakti, peneliti membuat forum diskusi (mewawancarai beberapa mahasiswa pada satu ruangan dengan melempar beberapa pertanyaan masalah keseharian untuk melihat pola pikir dampak pendidikan akuntansi pada kehidupan sehari-hari.

Untuk meminimalkan dugaan bahwa hanya akuntansi penyebab utama pola pikir mahasiswa, maka peneliti juga menanyakan latar belakang keluarga apakah agamis atau mengikuti suatu organisasi yang agamis. Peneliti tidak men-judge objek penelitian benar atau salah, hanya melihat dari sudut pandang berbeda yang menjadi latar belakang memperkuat bahan penelitian bahwa dengan dugaan pola pendidikan akuntansi mahasiswa dan lulusan akan bergantung seluruhnya pada uang yang berakibat mahasiswa nantinya tunduk patuh pada sebuah sistem kapitalis (orang kapitalis, pasar dan sebagainya). Di mana temuan ini yang menjadi dukungan bahwa fiqih mumalah menjadi penting dalam bagian pendidikan akutansi khususnya 
akuntansi syariah.

\section{HASIL DAN PEMBAHASAN \\ Risiko dan Manfaat Fiqih Mumalah}

Dengan memasukan bahasan fiqih muamalah yang seimbang pada bahasan akuntansi syariah, mahasiswa dapat secara aplikatif menerapkan ilmu yang diperoleh tanpa menunggu kelulusan dengan apa yang sudah dipelajari sehingga kesan akuntansi syariah menjadi tidak egoistik yang hanya bermanfaat bagi golongan tertentu. Jika akuntansi syariah hanya berfokus pada pelaporan keuangan, maka dapat diterapkan nanti saat lulus, itupun jika lulusan bekerja pada entitas syariah dimana saat ini jumlah lembaga keuangan syariah (fokus pada perbankan) hanya sebesar 5\%, sedangkan 95\% adalah perbankan konvensional, belum lagi saingan dengan industri lain non bank. Dan jika hanya berfokus pada bank maka hanya memiliki manfaat pada golongan tertentu. Sedangkan jika fiqih muamalah memiliki komposisi yang seimbang, mahasiswa paham mengenai transaksi syariah, diterapkan pada kehidupan sehari-hari, dan juga bermanfaat bagi kerabat (tidak egois), hal ini akan mejadi pola dakwah bergulir yaitu dosen mengajar pada mahasiswa kemudian mahasiswa bisa mengajarkan kembali kepada keluarga dan kerabat dekatnya.

Hal yang sejalan juga diperkenalkan oleh (Triyuwono, 2012) bahwa sumber utamanya adalah ketauhidan. Tiga komponen yang menunjukan ketauhidan dalam akuntansi syariah yaitu pengetahuan, keimanan dan tindakan sehingga secara sempurna metode pembelajaran yang selalu mengingat Tuhan dengan harapan para akuntan memiliki akhlak yang baik yang tidak hanya tunduk patuh pada perlakuan pasar modal kini bisa terlaksana dengan kepahaman dan kerelaan pihak-pihak yang menjalani transaksi. Sehingga pentingnya perbaikan akhlak dan pemahaman syariah perlu ditanamkan dalam metode pembelajaran akuntansi

Jika akuntansi syariah hanya berfokus pada pelaporan keuangan, lalu apa perbedaan antara akuntansi syariah dengan akuntansi yang lain yang mengedepankan angka-angka sehingga lulusan akan mengukur segala sesuatunya pada unit moneter dan melakukan sesuatu atas dasar analisis uang, dampaknya adalah uang dijadikan sebagai tempat bergantung yaitu segala sesuatu hanya dapat dilakukan jika ada uang.

Dari hasil observasi ditemukan bahwa setiap ada masalah dalam kehidupan sehari-hari dari 15 mahasiswa, 14 mahasiswa menangani masalah dengan uang yaitu hal pertama kali diingat adalah uang untuk menghadapi masalah sehari-hari, baik yang muslim, non muslim, berlatar belakang keluarga yang agamis ataupun tidak agamis, 14 jawaban mahasiswa menyirat uang sebagai tempat bergantung, padahal dalam Qur'an Surat Al Ikhlas menyatakan bahwa Allah SWT adalah tempat meminta. "Allah tempat bergantung atas segala sesuatu hal"(QS.112:2).

Dan jika menggantungkan nasib kepada Allah Swt, maka Allah Swt akan mencukupi. Sehingga proses pengajaran berbasis ketauhidan mulai terbentuk."..barang siapa bertawakal kepada Allah, maka Allah akan mencukupi segala kebutuhannya" (QS. 65:3).

Bisa saja lulusan menjadi terbatas pemikirannya dan akan menganggap bahwa manusia tidak dapat melakukan apa-apa, termasuk dalam ruang lingkup pemikiran entitas tidak dapat bergerak jika tidak ada uang. Kemungkinan lainnya adalah lulusan yang tidak bekerja pada entitas syariah namun lebih memilih berwirausaha agar kehidupan lebih sejahtera dan makmur, hal tersebut juga merupakan pemikiran yang tidak berketauhidan, karena kesejahteraan dan kemakmuran bukan didasarkan pada berwirausaha dan uang, tapi Tuhan yang memberikan kesejahteraan dan kemakmuran. Hal ini mengembalikan makna syariah yang merujuk pada Al Qur'an dan Hadits.

Selain itu nilai luhur yang diperoleh tidak lagi dunia, tapi mencapai pada falah (kemenangan) karena tujuan dari berwirausaha, bekerja pada entitas syariah dan segala seuatu yang didasarkan pada Alquran dan hadits memiliki cita-cita yang lebih ting- 
gi yaitu surga, mahasiswa dan lulusan tidak lagi menjalakan transaksi yang hanya pada kesan mencari materi dunia, tapi lebih dari itu yaitu falah.

Dampak lainnya adalah, lulusan yang bekerja pada suatu entitas akan beranggapan bahwa stakeholder tertinggi adalah manajer dan owner, yang akan menjadikan karyawan tunduk dan patuh pada perintah atasan untuk memenuhi kebutuhan pasar bagaimanapun caranya. Padahal jika kita menempatkan Allah sebagai stakeholder tertinggi mengalahkan siapapun termasuk owner dan manajer, para lulusan nantinya akan memiliki prinsip hidup dan akan tetap mematuhi manajer dan owner karena Allah yang memerintahkan untuk patuh terhadap pemegang kekuasaan, hal ini tercantum dalam QS. 4:59 yaitu setelah dianjurkan mematuhi Allah Swt dan Rasulnya, selanjutnya yang harus dipatuhi adalah ulul amri (pemegang kekuasaan setempat). Dalam hal ini jika karyawan bekerja di entitas syariah maka wajib mematuhi perintah atasan, dengan demikian perilaku-perilaku pekerja akan berubah dan berprinsip syariah bukan lagi berprinsip pada pemenuhan kebutuhan pasar.

Prinsip yang akan dipegang oleh mahasiswa dan lulusan adalah Alquran dan Hadits sebagai sumber hukum tertinggi mengalahkan sumber hukum apa pun. Sehingga para lulusan memiliki sikap idealis yang tidak bisa ditawar karena kebutuhan pasar. Maka akuntansi syariah adalah matakuliah yang tidak hanya berfokus pada kebutuhan pasar tapi juga memiliki focus utama mengembalikan kesadaran kepada Tuhan.

Dengan demikian dapat disimpulkan segala tindakan dan transaksi manusia akan dilihat dan dipertanggungjawabkan kepada Allah Swt sebagai stakeholder tertinggi dan menjadikan tuhan tempat bergantung serta menyadarkan manusia bahwa rizki bukan disebabkan oleh hasil kerja keras yang dapat melupakan waktu, tetapi rizki disebabkan oleh ketaqwaan. Hal ini dijelaskan dalam Alquran Surat At-Talaq yang berbunyi “..barang siapa bertaqwa kepada Allah, akan Allah berikan jalan keluar. Dan akan Allah berikan rizki dari arah yang tidak diduga- duga" (QS. 65:2-3).

Konsep seperti ini akan membuat manusia memiliki kesadaran baik saat bekerja akan bertanggungjawab pada stakeholder tertinggi yaitu Allah dan keluarga sebagai tempat dan bagian yang mendukung kesuksesan hidupnya. Manusia akan bekerja tidak pulang larut demi mengejar dunia dan unit moneter karena masih ada waktu untuk keluarga dan sekitarnya. Jadi rizki bukan membicarakan tentang kuantitas lama kita bekerja, tapi berbicara mengenai kualitas iman dan taqwa.

Sayangnya dari hasil observasi peneliti, seluruh mahasiswa yang memiliki IPK tertinggi yang menjadi objek penelitian dari seluruh kampus mengatakan jika ada pilihan antar pekerjaan dengan kompensasi besar dengan deadline pekerjaan selesai besok pagi dibanding dengan keluarga (orang tua) yang sedang sakit kritis, mereka akan memilih pekerjaan. Peneliti tidak menyalahkan jawaban objek peneliti, namun hasil ini menunjukan jerat-jerat kapitalis (Triyuwono, 2012) sudah mulai membentuk pola pikir mahasiswa yang bisa menyebabkan materalistis dan egoistis.

Risiko yang cukup mengkhawatirkan dan berdampak pada kesuksesan lulusan jika mahasiswa tidak dibekali fiqih muamalah, lulusan akan memiliki kepuasan jika bekerja sesuai dengan passion mereka, bagi mahasiswa akuntansi maka akan cocok bekerja pada bidang finance dan accounting. Seperti contoh lulusan yang bekerja memliki jobdesk terhadap pencatatan obligasi, atau penerapan yang berkaitan dengan bank. Hal ini akan memiliki risiko yang signifikan terhadap kesuksesan mahasiswa.

Pencatatan obligasi, bunga, bank, yang memiliki unsur riba akan berpengaruh terhadap penghasilannya menjadi penghasilan yang tidak halal sebagaimana sabda Rasulullah Saw: "Rasulullah salallahu alaihi wasalam Mengutuk orang yang makan harta riba, yang memberikan riba, penulis transaksi riba dan kedua saksi riba. Mereka semuanya sama."(HR. Muslim).

"Dosa riba terdiri dari72 pintu. Dosa riba yang paling ringan adalah seorang lakilaki yang menzinai ibu kandungya" (HR. 
Thabrani). "Sesungguhnya 1 dirham yang didapatkan oleh seorang laki-laki dari hasil riba lebih besar dosanya di sisi Allah daripada berzina 36 kali" (HR. Ibnu Abi Dunya).

Sebagai bahan perbandingan, riba juga dikecam pada agama lain yaitu Kristen (Nasrani) dan Yahudi seperti dalam kitab mereka mengatakan: "Dan, jikalau kamu meminjamkan sesuatu kepada orang karena kamu berharap akan menerima sesuatu darinya, apakah jasamu? Orang-orang berdosa pun meminjamkan kepada orang berdosa supaya mereka menerima kembali sama banyak. Tetapi kamu, kasihanilah musuhmu dan berbuatlah baik kepada mereka dan pinjamkan dengan tidak mengharapkan balasan, ...”(Lukas 6:34-35)- Kristen (Nasrani)

"Janganlah engkau mengambil bunga uang atau riba darinya, melainkan engkau harus takut akan Allah-mu, supaya saudaramu bisa hidup diantaramu. Janganlah engkau member uangmu kepadanya dengan meminta bunga, juga makananmu janganlah kau berikan dengan meminta riba" Kitab Yahudi Levicitus (Imamat) pasal 25 ayat 36-37.

Berdasarkan ayat-ayat pada kitab lain, terdapat pelarangan terhadap transaksi riba karena merupakan perbuatan yang menganiaya orang lain, baik transaksi riba itu dilakukan secara rela atau pun tidak rela. Karena pada dasarnya, kerelaan hanya terdapat pada jual beli, bukan kerelaan pada transaksi riba. Dikotonomi yang menjelaskan antara jual beli dengan riba dijelaskan dalam QS. Albaqarah 2:275 di mana jual beli mengandung keberkahan dan riba mengandung kecaman akan kehancuran secara global.

Jika kecaman dari ayat dan hadits di atas dihiraukan, maka pertanyaan berikutnya adalah "apa idealis teratas para mahasiswa sehingga Alquran dan hadits tidak begitu diindahkan?" Kebiasaan masyarakat) yang menyalahi syariah sudah menjadi budaya. Kekhawatiran itu sudah tertuang dalam perkataan Rasulullah Saw yaitu: "akan datang suatu masa, orang-orang tidak peduli dari mana harta dihasilkannya, apakah dari jalan yang halal atau dari jalan yang
haram"(HR. Bukhari).

Dampak dari harta haram yang diperoleh lulusan akan berpengaruh terhadap kesuksesannya karena Allah Swt merupakan pemberi kesuksesan baik diminta atau tidak. "Rasulullah membacakan Al Mu'minum: 51 dilanjut dengan Al Baqara: 172, kemudian beliau menyebutkan seorang lelaki yang mengadakan perjalanan jauh, berambut kusut dan berdebu, menadahkan tanggannya ke langin "Ya Rabb, Ya Rabb" padahal makanannya berasal dari yang haram, minumannya berasal dari yang haram, pakaiannya berasal dari yang haram dan makan dari yang haram, maka bagaimana doanya akan dikabulkan”(HR. Muslim).

Berdasarkan hadits tersebut bias dipetik pelajaran bahwa dengan datangnya musibah-musibah yang menimpa seseorang, sesungguhnya berasal dari dosa-dosa yang mereka berbuat, salah satunya adalah memperoleh harta non halal. Walaupun mahasiswa tidak mengetahui hartanya bercampur dengan harta haram, akan memiliki konversi (berupa musibah). dapat juga dianalogikan harta haram adalah racun, baik kita mengetahui atau tidak mengetahui yang akan kita minum racun, tubuh akan tetap menerima dampak dari racun tersebut. Dapat disimpulkan musibah yang manusia peroleh berawal dari kesalahan-kesalahan yang diperbuat olehnya termasuk kesalahan dalam bentuk memperoleh harta non halal. "Dan musibah apapun yang menimpa kamu adalah karena perbuatan tanganmu sendiri..."(QS. 42:30).

Sayangnya hasil observasi sebanyak 15 mahasiswa dari beberapa kampus hanya 1 mahasiswa yang menjawab bahwa setiap masalah yang dihadapi yang diingat pertama kali bukan uang melainkan kesalahankesalahan yang telah dilakukan. Hal-hal terkait risiko yang harus dihindari jika tidak memahami fiqih muamalah, begitu juga manfaat yang dapat diambil jika memahami fiqih muamalah di atas akan mendukung capaian pembelajaran jurusan. Dapat dilihat dari capaian pembelajaran pada sub point sikap, point pertama adalah bertaqwa kepada Tuhan Yang Maha Esa. Dalam proses pencapaian ketaqwaan, manusia harus memiliki 
sifat keimanan terlebih dahulu, yang diterangkan dalam Surat Al baqarah yang artinya:“..pentunjuk bagi mereka yang bertaqwa. Yaitu orang-orang yang beriman kepada yang ghaib..."(QS. 2:2-3).

Abstrak (ghaib) tidak hanya mengenai makhluk, tapi perkara-perkara yang tidak dapat dilihat seperti janji-janji Allah Swt, surga dan neraka, para nabi serta kaumkaum terdahulu termasuk ancamanancaman Allah tersebut dapat dikatakn ghaib, perkara ghaib ini dapat dilihat dalam Tafsir Ibnu Katsir. Hal ghaib tersebut juga merupakan sebuah konsep pembelajaran yang ditawarkan oleh Byrne dan Flood (2004), di mana salah satunya yaitu learning as the abstraction of meaning. Sayangnya konsep pembelajaran ini sedikit digunakan. Mengejutkannya lagi, hasil observasi seluruh objek penelitian tidak mengetahui ciri-ciri taqwa baik yang versi muslim maupun nonmuslim.

Dengan demikian sebuah capaian pembelajaran tidak hanya mencantumkan kata taqwa, tapi sebagai pengajar juga harus memahai esensi dari taqwa itu sendiri. Seluruh mata kuliah tidak hanya yang bersifat agamis tapi juga kapitalis mencantumkan point capaian pembelajaran ini. Jika taqwa yang identik dengan keagamaan adalah mencapai suatu proses pendekatan diri kepada Tuhan dan menjauhi larangan Tuhan, namun tidak mengerti halhal apa saja yang diperbolehkan dan dilarang. Apakah ini juga bagian dari taqwa? Sebagai contoh pembelajaran akuntansi yang identik dengan hutang dan bunga di mana hal ini diyakini dengan riba, namun mahasiswa tidak mengetahui ini sesuatu yang tidak baik, maka point taqwa tidak semestinya tercantum dalam capaian pembelajaran mata kuliah tersebut, kecuali pengajar memberikan warning yang diajarkan ada hal yang dibolehkan dan dilarang dalam koridor tertentu.

\section{Implementasi Fiqih Muamalah}

Penerapan fiqih muamalah dalam akuntansi syariah dapat diberi komposisi seimbang sehingga akuntansi syariah mem- iliki nilai lebih dalam mengembalikan kesadaran kepada Tuhan. Transaksitransaksi syariah banyak menggunakan istilah asing, contohnya murabahah, salam, istishna, mudharabah, musyarakah, ijarah dan sebagainya. Hal ini akan memberatkan mahasiswa yang baru mendengar istilah tersebut langsung masuk pada proses pelaporan keuangan, walaupun pengertian di atas dibahas sekilas dan sudah terdapat pada Pernyataan Standar Akuntansi Keuangan (PSAK).

Komposisi ini juga terlihat pada Ujian Sertifikasi Akuntansi Syariah yang diadakan oleh Ikatan Akuntan Indonesia (IAI) di mana level pertama membahas tentang berbagai jenis transaksi dan sumber hukum Islam sebelum memasuki ujian level kedua yaitu PSAK Syariah. Namun ketika fiqih muamalah dimasukan lebih kental, maka mahasiswa mulai menyadari substansi transaksi lebih mendalam bahkan dapat dipraktekan dalam kehidupan sehari-hari tanpa harus menunggu bekerja yang berkaitan dengan entitas syariah. Sehingga mata kuliah akuntansi syariah memiliki multi goals (tujuan ganda) yaitu mahasiswa dapat menjalankan berbagai transaksi yang tidak bertentangan dengan syariah agar terhindar dari harta haram dan mereka siap pakai dalam dunia kerja jika bekerja pada entitas yang berkaitan dengan syariah.

Penerapan fiqih muamalah, sebagai contoh, sebelum membahas akuntansi murabahah (jual beli yang menyebutkan harga pokok), mahasiswa dapat diperkenalkan terlebih dahulu jual beli berdasarkan perspektif syariah, yaitu mengenal syarat jual beli apa saja yang diperbolehkan, jenis dan proses jual beli apa saja yang dilarang, besar penetapan harga dalam menjalankan jual beli dan sebagainya.

Pengajar dapat memberikan pengaplikasian yang biasa dijumpai mahasiswa dalam aktivitas sekitarnya sehari-hari sehingga memudahkan mahasiswa langsung menerapkan hal tersebut. Setelah membahas fiqih muamalah, baru kemudian mahasiswa memasuki ranah akuntansi, sehingga analsis mahasiswa lebih tajam dalam menghadapi 
transaksi. Terlebih pada pertemuan pertama, pengajar dapat memotivasi pentingnya mempelajari fiqih muamalah. Hal ini sejalan dengan salah satu konsep pembelajaran yang dikenalkan oleh Byrne \& Flood (2004) yaitu learning as the abstraction of meaning. Dengan penerapan fiqih muamalah diharapkan aktif bagi mahasiswa meningkatkan keimanan dan ketaqwaan.

Penerapan lain yaitu dibentuk pra mata kuliah akuntansi syariah sebagai pra syarat, misal mata kuliah fiqih muamalah, namun jika pasaran masih belum menerima, maka dapat dinamakan akuntansi syariah 1 yang membahas fiqih muamalah, lembagalembaga terkait entitas syariah baik formal dan non formal serta lembaga penunjang seperti Otoritas Jasa Keuangan, Lembaga Arbitrase Syariah yang menagani sengketa transaksi syariah, pasar modal syariah dan sebagainya. Sehingga akuntansi syariah 2 akan dapat fokus membahas pelaporan keuangan entitas syariah serta kelebihan dari sisi finance. Hal ini dapat dilakukan jika standar-standar akuntansi syariah mulai banyak dimana tidak akan cukup lagi dibahas hanya pada satu mata kuliah. Seperti contoh akuntansi dasar, akuntansi menengah dan akuntansi lanjutan yang mengakomodasi standar-standar akuntansi keuangan yang sudah banyak.

Cara lainnya adalah teknis beberapa mata kuliah yang sudah dibahas dan mirip dengan akuntansi keuangan tidak dibahas lagi dalam akuntansi syariah, melainkan perbedaan yang mendasar seperti akuntansi istishna sudah pernah dibahas dalam akuntansi kontrak konstruksi, sukuk mirip dengan obligasi dan ijarah yang mirip dengan leasing. Pokok bahasan ini dapat dibahas hanya pada perbedaan akad, isu finance kelebihan setiap produk akad dibanding konvensional serta hanya perbedaan akun. Sehingga bahasan lain dapat lebih diperdalam lagi.

Temuan terakhir adalah jika fiqih muamalah tidak dimasukan, maka dosen membuat literatur untuk dibagikan kepada mahasiswa untuk belajar secara mandiri sehingga di kelas dosen dapat memberikan tes lisan sementara untuk mereview mahasiswa dalam menggunakan literatur yang dosen berikan. Selebihnya akuntansi dapat diterapkan lebih banyak di kelas.

\section{KESIMPULAN DAN SARAN}

Fiqih muamalah merupakan inti untuk berbagai macam transaksi. Bagi yang tidak memahami fiqih muamalah akan memungkinkan seseorang memperoleh harta yang tidak halal yang mungkin disebabkan dari 'urf (kebiasaan masyarakat). Risikorisiko yang dihadapi bagi mahasiswa yang tidak mengerti fiqih muamalah adalah: (1) ilmu akuntansi syariah hanya dapat digunakan nanti setelah lulus, itupun jika lulusan bekerja pada entitas syariah; (2) akan bertendensi memiliki jiwa materalisitik yaitu mengukur segala sesuatu dengan uang; (3) menjadikan uang dan selain tuhan sebagai tempat bergantung; (4) kebanggaan dalam menjalankan pekerjaan yang tidak diketahui apakah pekerjaan tersebut bertenetangan dengan syariah, dan (5) menganggap stakeholder tertinggi adalah owner dan manajer.

Sedangkan jika mahasiswa memiliki pemahaman terhadap akuntansi syariah akan memiliki manfaat: (1) penerapan ilmu langsung dapat diaplikasikan dalam kehidupan sehari-hari tanpa menunggu kelulusan (2) menjadikan Tuhan sebagai tempat bergantung hingga dapat mencapai pemahaman hakikat hamba yang sesungguhnya (3) dapat menghindari pekerjaan dan aktivitas yang haram (4) meyakini Tuhan sebagai stakeholder tertinggi (5) menuju pada ketaqwaan sebagai penunjang dalam memperoleh capaian pembelajaran.

Adapun implementasi dalam pengajaran adalah: (1) komposisi fiqih muamalah diterapkan secara seimbang dengan akuntansinya. Fiqih muamalah sebagai pengantar kemudian disusul dengan proses pelaporan keuangan; (2) membuat mata kuliah prasyarat akuntansi syariah yaitu fiqih mumalah dan lembaga penunjang transaksi syariah dengan nama akuntansi syariah 1 dan akuntansi syariah 2 , yang berfokus pada akuntansi dan keuangan syariah; (3) teknis beberapa mata kuliah yang sudah dibahas dan mirip dengan akuntansi keu- 
angan tidak dibahas lagi dalam akuntansi syariah, dan (4) dosen membuat literatur untuk dibagikan kepada mahasiswa untuk belajar secara mandiri.

\section{DAFTAR PUSTAKA}

Adnan, M.A., dan Gaffikin, M., 1997. The Shari'ah, Islamic Banks and Accounting Concepts and Practices. Paper presented at Accounting, Commerce and Finance: the Islamic Perspective International Conference, University of Western Sydney, Macarthur

Byrne, M., \& Flood, B. (2004). Exploring the conceptions of learning of accounting student. Accounting Education , 2537.

Clayton, P. R. (2012). Accounting curriculum redesign: Improving CPA Exam PassRates at a small university. Journal of Business Administrasion Online , 114.

Departemen Agama Republik Indonesia. (1986). Al-Quraan dan Terjemahanya. Jakarta: Departemen Agama.

Mahdavikhou, M., \& Khotanlou, M. (2012). New Approach to Teaching of Ethics in Accounting "Introducing Islamic Ethics into Accounting Education". Elsevier Social and Behavioral Sciences , 1318-1322.

Meier, H. H., Kamath, R. R., \& he, Y. (2010). Courses on Forensic and Fraud Exmanination in the Accounting Curriculum. Journal of Leadership, Accountability and Ethic , 25-33.

Mulawarman, A. D. (2006). Pensucian Pendidikan Akuntansi. Merefleksikan Domain Pendidikan Ekonomi dan Bisnis. Salatiga: Universitas Kristen Satya Wacana.

Mulawarman, A. D. (2008). Pensucian Pendidikan Akuntansi Episode Dua: Hiper View of Learning dan Implementasinya. Jurnal Telaah Ilmiah Akuntansi , 53-66.

Tarmizi, E. (2016). Harta Haram Muamalat Kontemporer. Bogor: Berkat Mulia Insani.
Triyuwono, I. (2013). [Makrifat] Metode Penelitian Kualitatif [Dan Kuantitatif] Untuk Pengembangan Disiplin Akuntansi. Simposium Nasional Akuntansi 16 (pp. 1-15). Manado: Universitas Sam Ratulangi.

Triyuwono, Iwan dan Moh. As'udi. (2001). Akuntansi Syariah: Memformulasikan Konsep Laba Dalam Konteks Metafora Zakat. Edisi Pertama. Jakarta: Penerbit Salemba Empat.

Triyuwono, I. (2012). Akuntansi Syariah: Perspektif, Metodologi dan Teori. Jakarta: Rajawali Pers.

Watts, R. L., \& Zimmerman, J. L. (1986). Positive Accounting Theory. United States: Pearson Education.

Wilkin, C. L., \& Collier, P. A. (2009). A Problem based Approach to Accounting Education: A Pragmatic Appraisal of a Technologically Enabled Solution. International Journal of Education and Development using Information and Communication Technology (IJEDICT) , 49-67. 